\title{
Religious Education in the Religion-State Relations after Independence of Kazakhstan
}

\author{
İlyas ERPAY ${ }^{1}$, Hazret Tursyn ${ }^{1} \&$ Zikriya Jandarbek $^{1}$ \\ ${ }^{1}$ A. Yassawi Kazakh-Turkish International University, Turkistan, Kazakhstan \\ Correspondence: İlyas ERPAY, A. Yassawi Kazakh-Turkish International University, Turkistan, Kazakhstan. \\ Tel: 772-5336-3628. E-mail: İlyas.erpay@yesevi.edu.tr; ilyaserpay@hotmail.com
}

Received: December 27, 2013

Accepted: February 28, 2014 Online Published: April 29, 2014

doi:10.5539/ass.v10n9p108

URL: http://dx.doi.org/10.5539/ass.v10n9p108

\begin{abstract}
According to the historical backgrounds the Republic of Kazakhstan was formed as the state with poly-ethnicity and multi-confessional society. The main duty of the state is to achieve social-political stability by establishing interethnic consent and inter confessional tolerance. Particularly, it was urgently necessary to draw attention to implement fundamental religious reform for formation of secular state after abolishing atheistic system of totalitarian society. This article analyses the constitution of Kazakhstan and normative legal basis of special religious laws in details. Accordingly, present-day religious organizations and institutions are considered. Special attention is paid to results of influence on religion-state relations, especially to World Leaders and Traditional Religions conference which is hold on every three year in Kazakhstan. Besides, the state policy for religious education and upbringing issues of younger generation is analyzed by specific examples. This article is an attempt to draw a new scientific conclusion that the main key of religious tolerance in the state is the secular and religious education. For developing the content of the theme, authors emphasized a point on modern research methods and consequences of social sciences. During research the legal and normative documents were analyzed by historically comparative methods. And, we used special methods for political and social sciences in identifying purposes and tasks of state policy in updating religious education and upbringing. Used methods will favor the political-social evolution of conversion from atheistic to secular society.
\end{abstract}

Keywords: religion, religious education, religious-state relationship, problems of teaching religious studies

\section{Introduction}

Since Kazakhstan declared its independence, the idea of atheism that had prevailed in the Soviet Union, was replaced by the freedom of religion with engendered extensive and painful changes in the social, cultural and spiritual life of all groups of society. Kazakhstan began the dominance of different religious sects, which no one knew anything about, and up to this point has not heard anything about it. Representatives of these courses have found shelter in a country, where people had no access to spiritual values because of Soviet ideology, yearning to make up for lost time. Various religious groups were formed together with the demographic structure of the Republic of Kazakhstan consisting of different ethnic groups. In order to make a strong and powerful state, Kazakhstan has a rich variety of ethnic groups and religions, provided for a balanced and careful policy in this territory. For this purpose, in the first place, it was decided to hold the Congress of Leaders of World and Traditional Religions once in three years. Despite of the fact that there are many ethnic groups and religions in Kazakhstan, the search continues for mechanisms to protect their national identity, their traditional religious beliefs and convictions. Some of Kazakh youth fell under the influence of various religions which has nothing common with Islam. And other part, on the contrary, fell under strong ideology-religious influence of Muslim countries' concept as Iran, Arabia, Egypt, etc. Some of them which were adherents of national traditions, along with religion gave priority to national, spiritual and cultural values. For this reason, now there is a special need for training of qualified personnel in the field, which corresponds with modern theological disciplines, relying on traditional religious principles of a secular state based on ethnic and religious diversity of Kazakhstan.

\section{Kazakhstan Model in Religion-State Relations}

After independence in 1991, the Republic of Kazakhstan became a social, democratic, secular and legal state, where the Constitution guaranteed freedom of conscience and religion for every citizen. The country was very tolerated to different religions and religious organizations. As it is proclaimed in Article 1 of the Constitution 
"The Republic of Kazakhstan is a democratic, secular, legal and social state, the supreme values of the state are individual, his/her life, rights and freedoms" (Qazaqstan Respublikasynyn Konstitutsiassy, 1995: 1), notably religion was separated from the state on the principle of secularism in the country.

Further, in the second paragraph of Article 14 of the Constitution of the Republic of Kazakhstan, it states: "no one shall be subject to any kind of discrimination concerning the origin, social or employment status, property, sex, race, nationality, language, religion, beliefs, place of residence, or any other circumstances", which implies that the Constitution guaranteed the equality of all citizens, regardless of their ethnic background. In addition, according to Articles 19 and 22 of the Constitution, citizens have the right to use their native language and culture, to choose the language of communication, upbringing, education and creativity. Herewith the right to freedom of conscience must not specify or limit universal human and civil rights and responsibilities before the state. It means that the realm of freedom of conscience and religion are clearly delineated and freedom of conscience and religion is an inalienable right of every citizen.

After the declaration of independence, in Kazakhstan, the Law "On Freedom of Conscience and Religious Associations" was enacted on the $15^{\text {th }}$ January, 1992. This Law grants equal rights to religious organizations and associations. The first section of the Law expressly states: "This Law recognizes that the Republic of Kazakhstan is a democratic, secular state which respects the right of everyone to freedom of opinion, guarantees equality of citizens irrespective of their religion, recognizes the cultural and historical value of religion, combined with the spiritual heritage of Kazakhstan peoples and the importance of interfaith harmony, religious tolerance and respect for religious beliefs of citizens" (Qazaqstan Respublikassynyn 1992 zhylgy 15 qantardagy Zany, 1 tarau). The Article 3 of the Law gives the following expression: "The direct or indirect restriction of rights or any benefits to citizens based on their religion or excitement associated with this enmity and hatred, or offending the feelings of citizens, as well as followers of the desecration of venerated or other religion items, entail liability under the legislation of the Republic of Kazakhstan" (Qazaqstan Respublikassynyn 1992 zhylgy 15 qantardagy Zany, 3 tarau). It prevented a different attitude to the various beliefs of citizens.

Again, the Article 4 of this Law states, that religious groups are separated from the state. All religions and religious associations are equal before the law. No religion or religious groups enjoy any advantage over others. Religious associations do not perform any governmental functions. Also, the state does not interfere the religious activities, if they do not contradict the legislation. Besides, the state does not finance religious organizations. Religious associations do not participate in the election of state power and administration. Religious organizations are not allowed to form parties with religious specificity and also cannot provide them with financial support. Religious associations and organizations do not participate in political life on a level with all other citizens only in their own name. Religious associations must abide by the law and order.

Government helps to strengthen mutual tolerance and respect between citizens who believe or do not believe, between religious institutions and organizations. Trying to ensure the supremacy of a religion as the state is prohibited by law. People, brought up with the path of atheism began to show increased interest in religion in first years of independence. In result the number of religious organizations in the country instantly increased fivefold. "On January 1, 1990, there were 671 religious associations representing 10-15 establishments in Kazakhstan. By the beginning of 2007, their number had risen to 3783, representing more than 40 confessions and establishments connected with them.

Number of religious associations of Islamic faith has grown from 46 to 2144, the religious associations of Russian Orthodox Church from 62 to 270, the Roman Catholic Church from 42 to 95, Churches of Protestant from 521 to 1147. In addition, there are 27 religious associations representing Judaism, 4 - Buddhism, 49 nontraditional denominations for Kazakhstan and 33 religious charitable fund and other societies" (Government of the Republic of Kazakhstan dated on December 5, 2007 with N 1185). Law "On Freedom of Conscience and Religious Associations", published in 1992, prepared the ground for the spread and development of various religious denominations. These "greenhouse" conditions for their distribution have also created the position of equal respect for all religions and "soft" religious policy.

Institute of Political Decisions, acting as an independent thought analytic center in Kazakhstan, presented some data. According to this data $93 \%$ of populations living in Kazakhstan are adherents of one or another religion. $64 \%$ of them are Muslims and $29 \%$ - Christians. $6 \%$ of the population consider themselves atheists, much of them are city dwellers.

\subsection{Fundamental Factors of Religion-State Relations}

Factors, identifying religion-state relations in Kazakhstan, appeared clearly in recent years. Representatives of many religious group and associations took place in the Assembly of Peoples of Kazakhstan and the Commission 
on Human Rights under the direction of President of the Republic of Kazakhstan. Committee on Religious Affairs was created in December 2005, in the structure of Ministry of Justice of the Republic of Kazakhstan for realization of religious policy, which provides opportunities for the religious freedom of citizens, coordinating relations between the state and activities of religious associations and controls compliant with rules.

In the first years of independence the relationship between religion and the state was tolerated for all religions, without prejudice to any rights of religious groups, but over time these rights and conditions began to show the harmful consequences caused by some religious sects and groups to the Kazakhstan government, people and its national values. Representatives of some religious groups were reluctant to send their children to school. The army, and even representatives of fundamentalism were against the law and the government, using terror and destroying the unity and brotherhood of citizens. As a result of these actions the Law "On Freedom of Conscience and Religious Associations", published in 1992, was needed for a revision.

Committee for Religious Affairs was abolished and replaced with the Agency for Religious Affairs Republic of Kazakhstan in accordance with the Decree of the President of the Republic of Kazakhstan No. 14/2011 of 18 May, (Egemen Qazaqstan Gazeti, 2011). Agency is the central executive body, realizing the state leadership in the field of interfaith harmony, rights of citizens to freedom of religion and interaction with religious associations, as well as inter-sectorial coordination provided by the law. In accordance with determinate order in legislation, Agency carries out functions on the formation and implementation of main directions of the state policy in the area of citizens' rights to freedom of religion and interaction with religious associations; proposal development to improve the legislation of Kazakhstan; regulating the issues of citizens' rights to freedom of religion, as well as conducting outreach work on public policy issues in the area of citizens' rights to freedom of religion.

In an interview with journalist Alisultanov Kulanbai head of the Agency for Religious Affairs K. Lama Sharif saido that the main tasks of the Agency are: to develop proposals for the formation of public policy in the area of citizens' rights to freedom of religion and interaction with religious associations, comprehensive and objective study, generalization and analysis of the processes occurring in the country in the implementation of the rights of citizens to freedom of religion and the activities of religious organizations and missionaries. Evidence of this is the celebration of religious holidays such as Eid al-Adha (Islam) and Christmas Noel (Christianity) (Kulanbay, 2011).

Following the formation of the Agency for Religious Affairs the Law "On Freedom of Conscience and Religious Associations", published in 1992 was repealed and the Law of the Republic of Kazakhstan dated on October 11, 2011 No. 483 -IV "On religious activities and religious associations" was passed. The new law states that "The Republic of Kazakhstan is a democratic, secular state, affirms the right of everyone to freedom of conscience, guarantees the right of everyone regardless of their religious beliefs, recognizes the historical role of Islam Hanafi direction and Orthodox Christianity in the development of culture and spiritual life of the people, respect other religions, combined with the spiritual heritage of the people of Kazakhstan, recognizes the importance of interconfessional harmony, religious tolerance and respect for religious beliefs of citizens" (Qazaqstan Respublikassynyn 483-IV nomirli Zany). In accordance with Article 2, Part 4, Agency on Religious Affairs "takes part in the formation and implementation of the main directions of the state policy in the field of interaction with religious associations". The law "On religious activities and religious associations" on a new approach to religion-state relations, taking into account the values of history, culture and beliefs of people, the demographic structure of Kazakhstan, set to work of religion-state religious and thereby purposed to form its own model.

\subsection{Legislative Basis of Religious Activities}

According to the Law "On religious activities and religious associations", religious organizations which are not registered at the Agency for Religious Affairs, have no right to any activity. There is no way to any enforcement in the relation to religion of citizens of the Republic of Kazakhstan, foreigners and stateless persons, to participate or not participate in the activities of religious associations, relations in religious ceremonies and (or) in the teaching religious studies. It is not allowed any activities of the associations, conjugate violence against citizens of the Republic of Kazakhstan, foreigners and stateless persons or other harm injuring their health or the family breakdown and termination of relationship between relatives, damage to morality, violation of rights and freedoms of citizens, prompting citizens to refuse from execution of the duties prescribed by the Constitution and laws of the Republic of Kazakhstan, and other violations of the legislation of the Republic of Kazakhstan. Furthermore, according to Article 4 of this Law, the State has the right to value and control the religious associations, missionaries, spiritual (religious) educational organization. On the other hand for the reason of this law there is the right to carry out religious examinations and checking the lists of citizens-initiators of religious 
associations, coordinate the activities of foreign religious associations in the country, the appointment of foreign religious centers heads of religious associations in the Republic of Kazakhstan.

Within the framework of the Law "On religious activities and religious associations" issued in 2011 during a year between early 2012 and early 2013, all religious associations formed by the Law dated on 1992 have been registered at the Agency for Religious Affairs. Spiritual Administration of Muslims in Kazakhstan has an autonomous structure and all mosques and madrasahs related with them have been registered and have received appropriate permissions in accordance with new law. As a result, till re-registration and after re-registration the number of religious organizations in the Republic of Kazakhstan was reduced as follows:

Islam - from 2811 to 2229 ,

Orthodoxy from 304 to 280 ,

Pentecostal churches from 400 to 189 ,

Evangelical Christians-Baptists from 364 to 100 ,

Catholicism from 118 to 79 ,

Jehovah's Witnesses from 70 to 59 ,

Presbyterian churches from 229 to 55,

Seventh-day Adventists from 67 to 42,

Evangelical Lutheran Church from 32 to 13,

Methodists from 18 to 11 ,

New Apostolic Church from 47 to 8 ,

Hare Krishnan from 14 to 8 ,

Baha'is from 20 to 6 ,

Judaism from 26 to 4 ,

Buddhism from 4 to 2 ,

Mennonites from 6 to 1

Church of Jesus Christ of Latter-day Saints (Mormons) 1 to 2 .

In total all religious organizations were reduced from 4551 to 3088 in total (State and Religion, 2012: 18). Thus the beginning of the state control over the activities of religious organizations and associations began to clear the mechanism of religion-state relations.

\subsection{Kazakhstan Model of Religious Policy}

Since independence years, Kazakhstan interested organizations not only within the country but also abroad, trying to establish cooperation between them and thus continue the peace initiatives in this sphere. One of the first but significant steps was the organization of the Congress of Leaders of World and Traditional Religions, first held in Astana on 23-24 September 2003, which subsequently decided to be organized once in 3 years. The IV Congress held on May 30-31, 2012, which continued the work of peace on earth. The Congress aims to dialogue between the leaders of world and traditional religions, built on trust and mutual understanding, which will open up broad prospects for international cooperation in this field and will contribute to overcoming such negative manifestations of our time, such as violence, extremism and terrorism. Congresses are hold in the new building, purpose-built for the forum "Palace of Peace and Harmony" in Astana.

Thus, Kazakhstan became a center of dialogue between religions and cultures of East and West. By holding the Congress of Leaders of World and Traditional Religions, Kazakhstan shows an example to the world community of national consensus and consolidation of society, creating a model of the relationship between religion and state. This model defines not only the relationship between religion and state it takes into account the interests of the public convenience and religious associations, democratic principles and respect for human rights and freedoms on the basis of mutual understanding. Religion is separated from the government, but society and the government is a single unit. A society cannot exist separately from religion. Thereby, harmful, moreover dangerous sects constitute a menace to society, and consequently to the government. In such situation, the task of the state is to regulate religious order in society. The special understanding on the relationship between religion and the state was created for save the security and tranquility for the people in Kazakhstan which is evolving towards peace and harmony. 


\section{Problems and Perspectives of Religious Education in Kazakhstan}

In most countries, the particular attention is paid to religious education; therewith the formation of the content of classes in religious studies the cultural, historical, religious and national values of the country are taken into account. After independence, the new generation of Kazakhstan has expressed keen interest in religion, that's why the number of those wishing to receive religious education has increased dramatically.

Freedom of conscience and religion, which destroyed the restrictions atheistic system, has madrasahs it possible to establish religious sites of worship. In order to remedy the lack of religious training and educate religious leaders, which were an urgent need in this period, Kazakhstan started to open various madrasahs. Some of them are Madrasah Abu Hanifa, Madrasah Abu Bakir Syddyk, Madrasah in Aktobe Madrasah in Astana, Madrasah in Ural, Saryagash Madrasah, Taraz Madrasah of Ibadullah, Ushkonyr Madrasah, Shymkent Madrasah, directly related to the Spiritual Administration of Muslims in Kazakhstan. Students in madrasahs are accepted on the recommendation of regional and district imams. Training period is 2 years and 10 months.

Along with religious subjects they teach subjects stated with standards of the Ministry of Education of Kazakhstan. Items such as Moral Foundations of Religion History, Arabic Language, History of Islam, Religious Dogmas, Kuran, Tajwid, Foundations of Worship, Sharia, Hadith, Teaching Religion Methods, Tafsir, History of Mazhab, Oratory, Fiqh combined with general subjects as: Basics of Economics and Rights, Ecology, Pedagogy, Pedagogy and Psychology, Cultural Studies, Basics of Philosophy, Kazakh Language, History of Kazakhstan, Political Science, Sociology and Computer Science. Religious disciplines consists $60 \%$ of the educational program, and general subjects - 40\%. Madrasahs graduates receive a diploma in "Religious Studies" (Derbisali, 2011: 23, 24)

Departments of Religious Studies and Theology are opened in universities under the Ministry of Education and Science of Kazakhstan. According to the standards of Ministry of Education and Science there are bachelor degree on 5B020600 - Religious Studies and 5B021100 - Theology, Master degree on 6M020600- Religious and 6M021100 - Theology and doctoral degree on 6D020600 - Religious studies and 6D021100 - Theology (special collection of graduate and postgraduate education of the Republic of Kazakhstan, 2009: 05.10.16) in social science departments. Universities, decided to open these specialty in its structure should prepare professionals, teachers and facilities, to establish an appropriate library fund, etc., that is completely prepare the necessary infrastructure, and only then submit an application to the Ministry of Education and Science. The ministry shall issue a license only if all the established requirements are kept by the university.

There are 146 universities in Kazakhstan, and only five of them have religion or theology programs. They are Al-Farabi Kazakh State University, International University of Foreign Studies and Careers, University of Nur-Mubarak, Gumilev Eurasian University, Akhmed Yassawi International Kazakh-Turkish University. Besides universities, Spiritual Administration of Muslims of Kazakhstan created the Islamic Institute in 2002 for professional development of imams. In certain period Imams of large and small mosques in Kazakhstan increase their qualifications in areas of knowledge, as the Koran, Fiqh, Arabic oratory Tajwid, the history of Islam, the Kazakh language, history of Kazakhstan, the philosophy of Islam, Tafsir, Hadith, religious dogma, Islamic science, İhsan, fundamentals of worship and moral principles.

\subsection{Religious Education at Schools}

In August 2009, the Ministry of Education and Science of Kazakhstan decided to enter 34 hours (two hours per week) religion into the secondary school curriculum (form 9), as an elective subject. Since the independence, the influx of missionaries and preachers began from various countries. The tasks of religious subject were the formation of unique perception of religion by students, protection of young people from the negative effects of dangerous religious movements and opposition to anarchism and extremism (Shepiev, 2009). Religion was introduced into the curriculum of secondary education with good purpose, to protect the public from false religious movements and the influence of missionaries, but because of the lack of well-trained teaching staff the agenda was a question of how and who will teach religious studies and what infrastructure is needed for this.

If we consider that Kazakhstan has about eight thousand schools, then how we can now find so many well-trained personnel for all schools? And is there any religious textbook corresponding to the level of pupils? Is there any need to teach a subject for all students or teach it as an elective one? If it is an elective subject, which religion will be studied exactly? And what happens if the missionaries who have already all the necessary and ready textbooks and learning, come to the school as teachers, preaching their own religious beliefs?

For them, this is the most opportune moment. Therefore, despite the fact that the teaching of religion is the good news, the above problems arouse serious doubts in society (Tasbolatov, 2013). 
After religion was introduced into the school curriculum as an elective subject, the government began to preparation of books and formation of their content. The first book was prepared by a team led by deputy philosopher G. Essim. The book titled as "Fundamentals of Religious Studies" published in 2010. According to the group, it was enough to acquaint students with the world religions and provide them with common views on religion.

At the same time the other group led by theologian D. Kenzhetai worked on a similar book. It was also published in 2010. The objective definition was given in the textbook; religion shows the relationship between religion and culture, revealing the role of Islam in shaping the traditional religious beliefs and culture of Kazakh people. From these two books for secondary schools, the Ministry of Education and Science of Kazakhstan chose one prepared under the supervision of G. Essim, even the book of D. Kenzhetay differed in content more acceptable in relation to national values.

The subject of Religious studies at schools should be taught by qualified specialists with higher education in this sphere, but unfortunately, the subject is taught by experts from other spheres, and sometimes experts from other spheres. Therefore, at the moment there is an urgent need to review the ways and methods of teaching religion, to organize training courses for teachers of this subject (Kuzembaeva, 2013).

Before the state introduced the subject of religion at schools, representatives of non-traditional religions, who arrived from other countries, got the opportunity to spread their beliefs. These religious groups under various pretexts were able to implement their ideas in the curriculum and religious outlook affect adolescents and youth. It come down to that the book "Path of Abai" (Abai zholy) issued by Dossym Omarov, representative of Hare Krishna in Kazakhstan was used in the school curriculum for a few years.

The classic of Kazakh literature Abay Kunanbayev's religious views combined with the teachings of Krishna in the book and be taught in this form. After fierce criticism on the textbook by specialists in Abai studies, after establishing the facts inconsistencies and contradictions in the book written by the traditional view of Kazakh people, the book was removed from the curriculum (Shoiymbet, 2008).

On the other hand the guise of Islam in Kazakhstan feels free to representatives of Wahhabism, which began active promotion of his teachings among youth. At first, Kazakh people were not able to distinguish the line between these groups and teachings of traditional Islam. As a result, Wahhabism rushed to political purposes even it had a few cases of terrorist acts in the country.

Young people fallen into Wahhabism net began to understand that they were going against traditional Islam of the Kazakh people, against his/her traditions, against national values after government established negative impact of these religious groups and had begun to take the appropriate measures against. At the same time, on the basis of such examples Kazakhstan scientists began to understand how harmful non-traditional religious teaching is. There were publications and editions, revealing the essence of these negative phenomena and the state with citizens started fighting against them. Kazakh enlighteners particularly stressed the need for control on religion by the state, drawing attention of government agencies to the need for discourages, any trends that deplete the outlook and views of traditional religions.

\section{Conclusion}

Along with the increased interest in faith and religious education, there was an acute dearth of quality teachers, as well as the available specialists often taught wrong; religion has been used for political purposes.

Lack of religious education and knowledge in this sphere, inherited from the Soviet Union to Kazakh people, a variety of ethnic groups, the presence of a large number of religious groups professing different creeds, and increase the amount of harmful religious movements within the country; lack of religious education specialists; opposing national traditions and values views of those who returned to the country, educated religious studies abroad; lack of faculties providing religious education, the lack of government measures on education and training of specialists in religious studies between citizens in their own universities; disadvantages of religious education at schools, all these issues require immediate and at the same time carefully checked solutions.

In order to train socialized, cultural, respectful relating to the eternal values, useful for a country person, the state first need to establish the base for education of specialists in this sphere. The state cannot stand aloof from the religion-state relations, so it should take into account its historical, cultural and religious values and begin extensive work in religious education of each representative of society.

In conclusion, it should be noted that the Muslim world, formed the basis of the history and culture of Kazakhs still poorly understood, and lack of systematic work in this direction does not allow it to pass to the next generation. In result, among some members of public there is a loss of religious and national values. In order to 
prevent these negative processes, it is required to make efforts to enhance the historical, cultural and religious identity of people. It would be better to start with the views and ideas of Akhmed Yassawi, a founder of Turkic-Islamic Synthesis, whose tomb is laid in the city of Turkestan, Republic of Kazakhstan. These views should be learnt and transmitted to future generations, because they professed values equally significant for Kazakhstan and also for the Turkic world.

\section{References}

Derbissali, S. A. K. (2011). Kazakstannyn Dini Oku oryndary, Almaty.

Egemen Kazakstan Gazeti, 21 Mamyr. (2011). Zhylgy.

Kazakstan Pespublikasy Ukimetinin 2007 Zhylgy 5 Zheltoksandagy no:1185 Kaulyssy. (n. d.). Retrieved October 22, 2011, from http://kz.government.kz/docs/p071185_20071205.htm

Kazakstan Respublikasy Din İsteri Agenttigi, Memleket zhane din. (2012). No: 4 (23), Astana.

Kazakstan Respublikasy Zhogary zhane Zhogary Oku Ornynan Keyingi Mamandyktar Zhikteuishi. (2009). Resmi Basylym, Astana.

Kazakstan Respublikasynyn 1992 zhylgy 15 Kantardağı Zany. (n. d.). Retrieved October 22, 2011, from http://adilet2.minjust.kz/kk/doc/show/75501

Kazakstan Respublikasynyn Konstitutsiasy. (1995). Retrieved October 22, 2011, from $\mathrm{http} / / / \mathrm{www}$. akorda.kz/kz/official_documents/the_constitution/the_constitution

Kazakstan Respublikasynyn no: 483-IV zany, Dini kyzmet zhane dini birlestikter turaly, Egemen Kazakstan Gazeti 15 Kazan 2001 zhylgy.

Kulanbay, Alisultan, Dini senimder arturli, al zan barshaga birdei, Egemen Kazakstan Gazeti, 14 Kyrkuek, 2011.

Kuzembaeva, A (2013). Kazakstandagy dini bilim beru zhuessi. Retrieved October 5, 2013, from http://www.baq.kz/kk/news/34669

Shepiev, B. (2009). Dintanu Panin Okytudyn Keibir Masseleleri Turaly Birer Soz. Retrieved October 15, 2011, from http://masa.kz/article/view/id/1485

Shoiymbet, J. (n. d.). Abai Men Shakarim Kagidalary nege burmalandy? Retrieved September 10, 2011, from $\mathrm{http} / /$ neweurasia.net/kazakhstan/қоғам-2/абай-мен-шәкәрім-қағидалары-неге-бұрм

Tasbolatov, E. (2009). Mektepterde Dintanu Sabagy Bastaldy. Retrieved October 10, 2011, from http://dinislam.kz/news/02092009_mektepterde_dintanu_sabay_bastaldy/2009-09-02-1431

\section{Copyrights}

Copyright for this article is retained by the author(s), with first publication rights granted to the journal.

This is an open-access article distributed under the terms and conditions of the Creative Commons Attribution license (http://creativecommons.org/licenses/by/3.0/). 